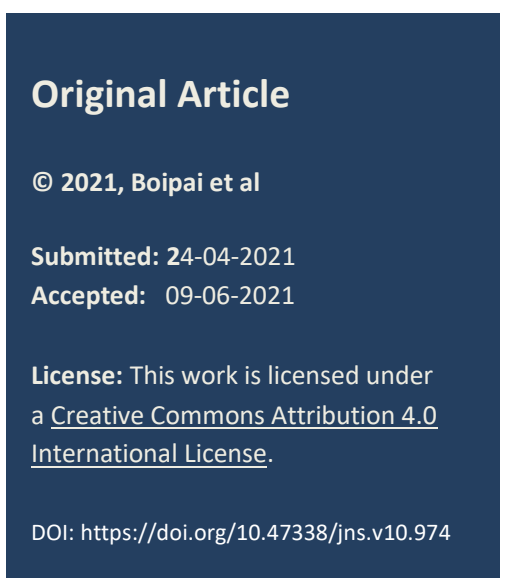

\title{
Dilemmas with surgical intervention in neonates with Necrotizing Enterocolitis without pneumoperitoneum
}

Manika Boipai, Rahul Gupta, ${ }^{*}$

Department of Paediatric Surgery, SMS Medical College, Jaipur, Rajasthan, India

Correspondence*: Department of Paediatric Surgery, SMS Medical College, Jaipur, Rajasthan, India.

E-mail: meetsurgeon007@gmail.com

\section{KEYWORDS \\ Necrotizing enterocolitis, Pneumoperitoneum, Perforation, Intestinal gangrene}

\section{INTRODUCTION}

Necrotizing enterocolitis (NEC) is seen in 1.1 per 1,000 live births.[1] The poor survival rate in NEC has been attributed to intestinal necrosis and perforation which could be treated by appropriate and timely surgical intervention. [2] Only abdominal free air during radiological investigations is universally accepted as an indication for surgery in NEC.[2] The operation should be performed during the "golden period" i.e., after the onset of intestinal gangrene but before intestinal perforation has occurred. This period is poorly characterized in neonates. Also, detection of NEC in the early stages to determine appropriate surgical timing is challenging as the indications for surgery have not been clearly defined.[3] It is estimated that $12 \%$ to $50 \%$ of neonates with perforation may not demonstrate free air. [4] The diagnosis of perforation in the absence of free air remains difficult and therefore the decision to operate must be based on the cumulative clinical and radiologic assessment of the patient.

This study was done to analyse the outcomes of two groups of surgically managed NEC patients based on the radiographic findings (presence or absence of pneumoperitoneum) and compare the actual surgical findings. Also, to study clinical and radiological findings that directed surgical intervention in these two groups of patients with NEC. 


\section{METHODS}

A prospective observational study was performed in the Pediatric Surgery department of a tertiary care teaching institute (India) for 17 months from October 2018 to February 2020. Approval of the study was taken from the hospital. Informed written consent was obtained from the patient's parents/guardian about the study and a detailed proforma was entered.
The diagnosis of NEC was made according to modified Bell's criteria (Table 1). [5, 6]

Patients between the ages of 1 to 90 days having preoperative clinico-radiological features consistent with NEC (based on modified Bell's criteria) and patients with an intraoperative picture of NEC (perforation/ Gangrenous or necrosis of bowel segment) were included in the study.

Table1: Modified Bell's staging criteria for Necrotizing Enterocolitis (NEC) [DIC: disseminated intravascular coagulation; NPO: "nil per oral" or nothing by mouth]

\begin{tabular}{|c|c|c|c|c|c|}
\hline Stage & Severity & Systemic signs & Abdominal Signs & $\begin{array}{l}\text { Radiographic Signs (X- } \\
\text { ray or ultrasound signs) }\end{array}$ & Treatment \\
\hline IA & Suspected NEC & $\begin{array}{l}\text { Temperature } \\
\text { instability, apnea, } \\
\text { bradycardia, } \\
\text { lethargy }\end{array}$ & $\begin{array}{l}\text { Gastric retention, } \\
\text { abdominal distension, } \\
\text { emesis, } \\
\text { heme-positive stool }\end{array}$ & $\begin{array}{l}\text { Normal or } \\
\text { intestinal distension, } \\
\text { mild ileus }\end{array}$ & $\begin{array}{l}\text { NPO, } \\
\text { antibiotics for 3days }\end{array}$ \\
\hline IB & Suspected NEC & Same as above & $\begin{array}{l}\text { Grossly bloody stool } \\
\text { Haematochezia }\end{array}$ & Same as above & Same as IA \\
\hline IIA & $\begin{array}{l}\text { Definite NEC, } \\
\text { mildly ill }\end{array}$ & Same as above & $\begin{array}{l}\text { Same as above, plus } \\
\text { absent bowel sounds } \\
\text { with or without } \\
\text { abdominal tenderness }\end{array}$ & $\begin{array}{l}\text { Intestinal dilation, } \\
\text { ileus, } \\
\text { pneumatosis } \\
\text { intestinalis }\end{array}$ & $\begin{array}{l}\text { NPO, } \\
\text { antibiotics for } 7 \text { to } \\
10 \text { days }\end{array}$ \\
\hline IIB & $\begin{array}{l}\text { Definite NEC, } \\
\text { moderately ill }\end{array}$ & $\begin{array}{l}\text { Same as above, plus } \\
\text { mild metabolic } \\
\text { acidosis, mild } \\
\text { thrombocytopenia }\end{array}$ & $\begin{array}{l}\text { Same as above, plus } \\
\text { absent bowel sounds, } \\
\text { definite tenderness, } \\
\text { with or without } \\
\text { abdominal cellulitis or } \\
\text { right lower quadrant } \\
\text { mass }\end{array}$ & $\begin{array}{l}\text { Same as IIA, plus } \\
\text { portal vein gas, with or } \\
\text { without ascites }\end{array}$ & $\begin{array}{l}\text { NPO, antibiotics for } \\
14 \text { days }\end{array}$ \\
\hline IIIA & $\begin{array}{l}\text { Advanced NEC, } \\
\text { Severely ill } \\
\text { (intact bowel) }\end{array}$ & $\begin{array}{l}\text { Same as IIB, plus } \\
\text { hypotension, } \\
\text { bradycardia, severe } \\
\text { apnea, combined } \\
\text { respiratory and } \\
\text { metabolic acidosis, } \\
\text { DIC, and } \\
\text { neutropenia }\end{array}$ & $\begin{array}{l}\text { Same as above, plus } \\
\text { signs of peritonitis, } \\
\text { marked tenderness, } \\
\text { and abdominal } \\
\text { distension }\end{array}$ & $\begin{array}{l}\text { Same as IIA, plus } \\
\text { portal vein gas, } \\
\text { definite ascites }\end{array}$ & $\begin{array}{l}\text { NPO, antibiotics for } \\
14 \text { days, fluid } \\
\text { resuscitation, } \\
\text { inotropic support, } \\
\text { ventilator therapy, } \\
\text { paracentesis }\end{array}$ \\
\hline IIIB & $\begin{array}{l}\text { Advanced NEC, } \\
\text { Severely ill } \\
\text { (perforated bowel) }\end{array}$ & Same as IIIA & Same as IIIA & $\begin{array}{l}\text { Same as above, plus } \\
\text { pneumoperitoneum }\end{array}$ & $\begin{array}{l}\text { Same as IIA, plus } \\
\text { surgery }\end{array}$ \\
\hline
\end{tabular}

Cases of neonatal perforation due to Ileal atresia, Meconium ileus, Hirschsprung disease, Gastroschisis, Meckel's diverticulum, Malrotation with volvulus, Traumatic etiology, Focal gastrointestinal perforation, Spontaneous pneumoperitoneum were excluded.

Management was based on criteria of development of surgical NEC features (clinical and radiological) and non-responsiveness to conservative management leading to further deterioration of the patient's condition, especially Stage I and II patients. The patients were referred from (a) medical neonatal intensive care unit (NICU) of our hospital, (b) referred to the surgical unit after primary treatment in other medical NICUs, (c) patients admitted directly to the neonatal surgical unit for primary treatment (i.e. not including the patients referred from NICUs). The initial treatment was supportive and consisted of nasogastric drainage and intravenous fluids to correct hypovolemia and/or acidosis. On admission, empirical broad-spectrum antibiotics were prescribed (Piperacillin with Tazobactam, Metronidazole, and Amikacin) as most of the patients had already received cephalosporin as the first line of treatment. All the patients were subjected to abdominal $\mathrm{x}$-ray in erect and/or supine positions; those with equivocal findings were subjected to lateral decubitus radiographs. Baseline blood investigation including complete blood counts, serum electrolytes, arterial blood gas, C- reactive protein levels, blood culture, renal and liver function tests were performed. Erythema and induration of anterior abdominal wall and abdominal tenderness along with other clinical parameters were monitored. Ventilatory and inotropic support was given depending on the patients' condition. Ultrasonography of the abdomen was done to evaluate for echogenic ascites, pneumoperitoneum, pneumatosis intestinalis, portal venous gas, and features of intestinal ischemia and gangrene. Radiological investigations were repeated at appropriate (6-12 hours) intervals.

Those neonates with marked abdominal distension and impending compartment syndrome and associated with very low birth weight or severe sepsis and 
shock (requiring ventilator / inotropic support) were subjected to bedside peritoneal drain placement as a temporizing measure. Apart from the medically managed ones, all the other patients underwent exploratory laparotomy and bowel resection. This was followed by enterostomy or anastomosis or anastomosis along with stoma depending on the status of the bowel. Operative findings of intestinal ischemia, necrosis, and/or bowel perforation in all surgical NEC patients were carefully recorded in proforma.

The operated patients were divided into two groups for comparison based on the preoperative presence (Group A) or absence (Group B) of pneumoperitoneum. Both groups were further compared based on the surgical findings and other variables related to morbidity and mortality such as duration of symptoms from onset to the day of surgery, days of conservative management prior to surgery in hospital, recovery, and mortality. In addition, charts were prepared on patients' demographic profile, clinical features, radiographic appearance, USG findings, type of surgery, and immediate postoperative complications. The patients were assessed after discharge for 3 months on follow-up. All statistical data analysis was obtained with the statistical package for social sciences (SPSS) version 10.0 for Windows. A "p" value of less than 0.05 was considered significant.

\section{RESULTS}

The study consisted of 81 patients diagnosed with NEC and admitted to the surgical unit with 63 (77\%) males and 18 (23\%) females [Table 2]. A majority $(55 \%)$ of them were preterm. Patients belonged to an age ranging from 1 to 90 days with a mean age of 12.9 days. The mean weight was $2330 \pm 708$ grams. Eleven $(13.5 \%)$ patients were of very low birth weight (weight $<1500$ grams) [Table 2].

The average time duration of symptoms (before presenting to our institute) was 4.1 days. Vomiting (60, 74\%) and abdominal distension (59, 73\%) were the most common symptoms. Features of obstruction were seen in one-fourth (26\%) of patients. Sepsis and shock were the presenting signs at the time of admission in more than one-third (36\%) of our patients. Thrombocytopenia was seen in $16(20 \%)$ and abdominal erythema in $15(18 \%)$ was also noted. Group-wise division is given in Table 3 and Table 4. Pre-operative inotropic was required in 10 (12\%) and ventilatory support in 19 (23\%) cases. Forty-three $(53 \%)$ of the patients were referred to the surgical unit after primary treatment in other medical NICUs and the rest $38(47 \%)$ were directly admitted to the neonatal surgical unit. The average duration of treatment in these NICUs was 8.6 days [Table 2].
In $20(24 \%)$ patients primary peritoneal drain was placed as a temporizing measure. Exploratory laparotomy was performed in 51 out of the 81 patients, and all surgical NEC patients had operative findings of intestinal ischemia, necrosis, and usually, bowel perforation. The remaining 30 patients were too sick (due to severe sepsis, shock), were medically managed, and could not be salvaged before surgical intervention could be undertaken.

Table 2: Demographic characteristics and clinical findings in our patients

\begin{tabular}{|c|c|}
\hline Demographic Data & Frequency (\%age) \\
\hline \multicolumn{2}{|l|}{ Sex distribution } \\
\hline Male & $63(77 \%)$ \\
\hline Female & $18(23 \%)$ \\
\hline \multicolumn{2}{|l|}{ Term distribution } \\
\hline Preterm neonates & $45(55 \%)$ \\
\hline Term neonates & $36(45 \%)$ \\
\hline \multicolumn{2}{|c|}{ Weight distribution } \\
\hline Weight $>2500$ grams & $28(34.5 \%)$ \\
\hline Low Birth Weight (<2500 grams) & $42(52 \%)$ \\
\hline Very Low Birth Weight (<1500 grams) & $11(13.5 \%)$ \\
\hline \multicolumn{2}{|l|}{ Clinical features } \\
\hline Vomiting & $60(74 \%)$ \\
\hline Abdominal distension & $59(73 \%)$ \\
\hline Features of sepsis / shock & $29(36 \%)$ \\
\hline Features of obstruction & $21(26 \%)$ \\
\hline Thrombocytopenia $\left(<50,000 / \mathrm{mm}^{3}\right)$ & $16(20 \%)$ \\
\hline Abdominal wall erythema & $15(18 \%)$ \\
\hline Features of GI bleed & $4(5 \%)$ \\
\hline \multicolumn{2}{|c|}{ Treatment history } \\
\hline Patients referred from medical NICUs & $43(53 \%)$ \\
\hline Pre-operative inotropic support & $10(12 \%)$ \\
\hline Pre-operative ventilator support & $19(23 \%)$ \\
\hline History of Umbilical catheterization & $2(2 \%)$ \\
\hline History of multiple blood transfusions & $7(9 \%)$ \\
\hline Primary peritoneal drainage & $20(25 \%)$ \\
\hline Characteristics & $\begin{array}{l}\text { Mean values } \\
\text { (Range) }\end{array}$ \\
\hline \multicolumn{2}{|c|}{ Distribution according to weight, maturity, and other factors } \\
\hline Age at presentation (days) & 12.9 days $(1-90)$ \\
\hline Weight at presentation (grams) & $\begin{array}{l}2330 \text { grams } \\
(1200-4800)\end{array}$ \\
\hline Duration of symptoms (days) & 4.1 days $(1-10)$ \\
\hline $\begin{array}{l}\text { Duration of conservative treatment in } \\
\text { medical NICUs (days) }\end{array}$ & 8.6 days $(1-15)$ \\
\hline $\begin{array}{l}\text { The total duration of hospital stay } \\
\text { (days) }\end{array}$ & 15.3 days $(1-27)$ \\
\hline
\end{tabular}


Out of these 51 patients with exploratory laparotomy, Group A (preoperative presence of pneumoperitoneum) comprised 35 (69\%) patients and Group B (preoperative absence of pneumoperitoneum) included 16 (31\%) patients (Fig.1). Group A underwent surgery because of the presence of pneumoperitoneum and clinical findings consistent with NEC. Group B had other clinical and radiological features precipitating surgery i.e. clinical deterioration, abdominal wall erythema, fixed bowel loop, metabolic derangement, etc. as shown in Table 3. Out of 16 cases in Group B, 6 $(37 \%)$ patients had features of clinical deterioration in the form of persistent sepsis and shock. These patients had progressive metabolic acidosis and dyselectrolytemia (Modified Bell's stage IIIA) 6 (37\%) and thrombocytopenia (Modified Bell's stage IIB) 6 (37\%). Clinical signs like abdominal wall erythema (Modified Bell's stage IIB) 4 (25\%) and fixed abdominal mass (Modified Bell's stage IIB) 1 (6\%) were present among group B patients. Radiographs and USG of Group B patients were evaluated. In the absence of free air, other predictors of NEC were detected. Fixed bowel loops (Modified Bell's stage IA/IB) in 3 (18\%), pneumatosis intestinalis (Modified Bell's stage IIA) in 1 (6\%), portal venous gas (Modified Bell's stage IIB) in 1 (6\%), and massive ascites (Modified Bell's stage IIIA) in $2(12 \%)$ patients were noted. These all contributed towards the diagnosis when pneumoperitoneum is absent. More than one clinico-radiological finding was present among the patients. Among Group B patients, 11/16 (69\%) had perforation, which was noted during surgery. The remaining 5/16 (31\%) had only gangrenous and necrosed bowel segments but no perforation [Table 3]. Clinico-radiological findings in Group A are presented in Table 4.

Table 3: Clinical, radiological, and operative findings in Group B patients

\begin{tabular}{|c|c|c|c|}
\hline \multicolumn{2}{|c|}{$\begin{array}{c}\text { Characteristic Findings in } \\
\text { Group B }\end{array}$} & $\begin{array}{l}\text { Modified } \\
\text { Bell's } \\
\text { stage }\end{array}$ & $\begin{array}{c}\text { Frequency } \\
\text { (\%age) }\end{array}$ \\
\hline \multirow{4}{*}{$\begin{array}{l}\text { Clinical } \\
\text { Features }\end{array}$} & $\begin{array}{l}\text { Abdominal wall } \\
\text { erythema }\end{array}$ & IIB & $4(25 \%)$ \\
\hline & $\begin{array}{l}\text { Fixed abdominal } \\
\text { mass }\end{array}$ & IIB & $1(6 \%)$ \\
\hline & $\begin{array}{l}\text { Clinical } \\
\text { deterioration }\end{array}$ & IIIA & $6(37 \%)$ \\
\hline & Thrombocytopenia & IIB & $6(37 \%)$ \\
\hline \multirow{4}{*}{$\begin{array}{l}\text { Radiological } \\
\text { Features }\end{array}$} & Fixed bowel loop & IA/IB & $3(18 \%)$ \\
\hline & $\begin{array}{l}\text { Pneumatosis } \\
\text { intestinalis }\end{array}$ & IIA & $1(6 \%)$ \\
\hline & Portal venous gas & IIB & $1(6 \%)$ \\
\hline & Massive ascites & IIIA & $2(12 \%)$ \\
\hline \multirow[b]{2}{*}{$\begin{array}{l}\text { Intraoperati } \\
\text { ve Features }\end{array}$} & $\begin{array}{l}\text { Presence of } \\
\text { perforation }\end{array}$ & & 11 (69\%) \\
\hline & $\begin{array}{l}\text { Gangrenous and } \\
\text { necrosed bowel } \\
\text { segment but no } \\
\text { perforation }\end{array}$ & & $5(31 \%)$ \\
\hline \multicolumn{2}{|r|}{ Total } & & $16(100 \%)$ \\
\hline
\end{tabular}

Table 4: Clinical, radiological, and operative findings in Group A patients

\begin{tabular}{|c|c|c|c|}
\hline \multicolumn{2}{|c|}{$\begin{array}{c}\text { Characteristic Findings in } \\
\text { Group A }\end{array}$} & \multirow{2}{*}{$\begin{array}{c}\begin{array}{c}\text { Modified } \\
\text { Bell's } \\
\text { stage }\end{array} \\
\text { IIB }\end{array}$} & \multirow{2}{*}{$\begin{array}{c}\begin{array}{c}\text { Frequency } \\
\text { (\%age) }\end{array} \\
11(31.4 \%)\end{array}$} \\
\hline \multirow{4}{*}{$\begin{array}{l}\text { Clinical } \\
\text { Features }\end{array}$} & $\begin{array}{l}\text { Abdominal wall } \\
\text { erythema }\end{array}$ & & \\
\hline & $\begin{array}{l}\text { Fixed } \\
\text { abdominal } \\
\text { mass }\end{array}$ & IIB & 3 (8\%) \\
\hline & $\begin{array}{l}\text { Clinical } \\
\text { deterioration }\end{array}$ & IIIA & $10(29 \%)$ \\
\hline & $\begin{array}{l}\text { Thrombocytope } \\
\text { nia }\end{array}$ & IIB & $10(28.6 \%)$ \\
\hline \multirow{4}{*}{$\begin{array}{l}\text { Radiological } \\
\text { Features }\end{array}$} & $\begin{array}{l}\text { Fixed bowel } \\
\text { loop }\end{array}$ & IA/IB & $3(8 \%)$ \\
\hline & $\begin{array}{l}\text { Pneumatosis } \\
\text { intestinalis }\end{array}$ & IIA & 0 \\
\hline & $\begin{array}{l}\text { Portal venous } \\
\text { gas }\end{array}$ & IIB & 0 \\
\hline & Massive ascites & IIIA & $5(14 \%)$ \\
\hline $\begin{array}{l}\text { Intraoperative } \\
\text { Features }\end{array}$ & $\begin{array}{l}\text { Presence of } \\
\text { perforation } \\
\text { with or without } \\
\text { gangrenous } \\
\text { and necrosed } \\
\text { bowel segment }\end{array}$ & & 35 (100\%) \\
\hline \multicolumn{2}{|c|}{ Total } & & $35(100 \%)$ \\
\hline
\end{tabular}

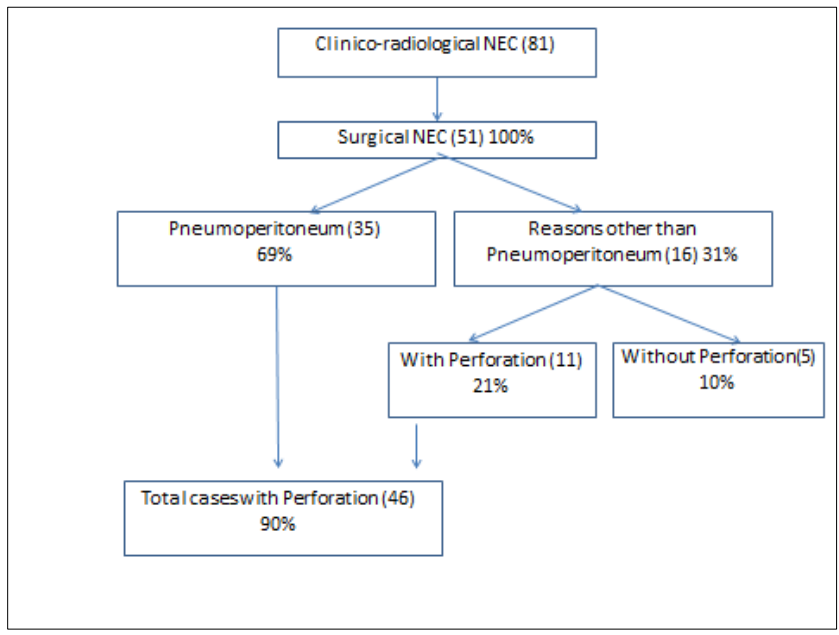

Figure 1: Indications for surgery in newborn with necrotizing enterocolitis (NEC). The absolute frequency is presented in parentheses

A comparative study was done between both groups [Table 5]. Group B patients had a longer duration of symptoms than Group A (mean days: 5.1 vs. 3.3). It implies a delay in diagnosis in the absence of pneumoperitoneum. Laparotomy in Group A was followed by enterostomy in most (48\%) of the cases. Rest underwent anastomosis (26\%) and anastomosis with enterostomy (26\%). In Group B, enterostomy (37\%), anastomosis (37\%), and anastomosis with enterostomy $(26 \%)$ were performed. Type of surgery i.e. stoma, anastomosis, and stoma with anastomosis were comparable in both the groups [Table 5]. Isolated small bowel involvement was seen to be more common in both the groups i.e. $65 \%$ and $56 \%$, in Group A and B respectively [Figure 2].

Outcomes were assessed in terms of complications, recovery, and deaths [Table 6]. The overall complica- 
tion rate was 67\%; Out of 35 patients in Group A, the complication rate was higher $(77 \%)$, while it was $43 \%$ (out of 16 patients) in Group B (statistically significant, $\mathrm{p}=0.01)$. Septicemia and fluid electrolyte imbalance was the most common (43\%) complication [Table 6]. Mortality was seen in a total of $31(61 \%)$ patients. This corresponds to $25(71 \%)$ neonates in Group A and $6(37 \%)$ in Group B (statistically significant, $\mathrm{p}=0.02)$. Hence the mortality and complication rates were worse in Group A. Better survival was seen in the patients when pneumoperitoneum was absent, i.e. $10(63 \%)$ patients recovered and were discharged in Group B in comparison to 10 (29\%) of Group A (statistically significant, $\mathrm{p}=0.02$ ).

Table5: Comparative operative details of two study groups

\begin{tabular}{|c|c|c|c|c|}
\hline \multicolumn{2}{|c|}{ Characteristics } & Group A & Group B & Total \\
\hline \multicolumn{2}{|c|}{$\begin{array}{l}\text { No. of patients in each } \\
\text { group (Frequency) }\end{array}$} & $\begin{array}{l}n=35 \\
(68 \%)\end{array}$ & $\begin{array}{l}n=16 \\
(32 \%)\end{array}$ & $\begin{array}{c}\mathrm{n}=51 \\
(100 \%)\end{array}$ \\
\hline $\begin{array}{c}\text { Symptom } \\
\text { s duration } \\
\text { in days }\end{array}$ & $\begin{array}{l}\text { Mean } \\
\text { (Range) }\end{array}$ & $\begin{array}{l}3.3 \text { days } \\
(1-5)\end{array}$ & $\begin{array}{l}\text { 5.1days } \\
(1-10)\end{array}$ & $\begin{array}{l}4.1 \text { days } \\
(1-10)\end{array}$ \\
\hline \multirow{3}{*}{$\begin{array}{l}\text { Type of } \\
\text { Surgery }\end{array}$} & Stoma & $17(48 \%)$ & $6(37 \%)$ & $23(45 \%)$ \\
\hline & $\begin{array}{c}\text { Anastomosi } \\
\mathrm{s}\end{array}$ & 9 (26\%) & $6(37 \%)$ & $15(30 \%)$ \\
\hline & $\begin{array}{c}\text { Stoma with } \\
\text { anastomosi } \\
\text { s }\end{array}$ & 9 (26\%) & 4 (26\%) & $13(25 \%)$ \\
\hline \multirow{2}{*}{$\begin{array}{l}\text { Segment } \\
\text { of bowel } \\
\text { involved }\end{array}$} & Single & $20(57 \%)$ & 9 (56\%) & $29(57 \%)$ \\
\hline & Multiple & $15(43 \%)$ & 7 (44\%) & $22(43 \%)$ \\
\hline \multirow{3}{*}{$\begin{array}{c}\text { Part of } \\
\text { bowel } \\
\text { involved }\end{array}$} & Small Bowel & $23(65 \%)$ & 9 (56\%) & $32(62 \%)$ \\
\hline & $\begin{array}{c}\text { Small bowel } \\
+ \text { large } \\
\text { bowel }\end{array}$ & $1(3 \%)$ & $1(6 \%)$ & $2(4 \%)$ \\
\hline & Large bowel & $11(32 \%)$ & $6(38 \%)$ & $17(34 \%)$ \\
\hline
\end{tabular}

Table 6: Comparative details of complications and outcomes of two study groups $[\mathrm{p}<0.05$ is considered significant]

\begin{tabular}{|c|c|c|c|c|c|}
\hline \multicolumn{2}{|c|}{ Characteristics } & $\begin{array}{c}\text { Group } \\
\text { A }\end{array}$ & $\begin{array}{c}\text { Group } \\
\text { B }\end{array}$ & Total & $\begin{array}{c}\mathbf{p} \\
\text { value }\end{array}$ \\
\hline \multicolumn{2}{|c|}{$\begin{array}{l}\text { No. of patients in each } \\
\text { group (Frequency) }\end{array}$} & $\begin{array}{l}n=35 \\
(68 \%)\end{array}$ & $\begin{array}{l}n=16 \\
(32 \%)\end{array}$ & $\begin{array}{l}n=51 \\
(100 \%)\end{array}$ & \\
\hline \multirow{6}{*}{$\begin{array}{c}\text { Post- } \\
\text { operative } \\
\text { complicat } \\
\text { ions } \\
\text { (Early) }\end{array}$} & Total & $\begin{array}{c}27 \\
(77 \%)\end{array}$ & $\begin{array}{c}7 \\
(43 \%)\end{array}$ & $\begin{array}{c}34 \\
(67 \%)\end{array}$ & \multirow{6}{*}{$\begin{array}{l}P= \\
0.01\end{array}$} \\
\hline & $\begin{array}{l}\text { Wound } \\
\text { infection }\end{array}$ & $\begin{array}{c}4 \\
(11 \%)\end{array}$ & $1(6 \%)$ & $\begin{array}{c}5 \\
(10 \%)\end{array}$ & \\
\hline & Leak & 1 (3\%) & $1(6 \%)$ & $2(4 \%)$ & \\
\hline & $\begin{array}{c}\text { Sepsis/ } \\
\text { Dyselectrolyt } \\
\text { emia }\end{array}$ & $\begin{array}{c}17 \\
(49 \%)\end{array}$ & $\begin{array}{c}5 \\
(31 \%)\end{array}$ & $\begin{array}{c}22 \\
(43 \%)\end{array}$ & \\
\hline & $\begin{array}{l}\text { Features of } \\
\text { obstruction }\end{array}$ & $3(9 \%)$ & 0 & $3(6 \%)$ & \\
\hline & $\begin{array}{c}\text { Stoma } \\
\text { Related }\end{array}$ & $2(5 \%)$ & 0 & $2(4 \%)$ & \\
\hline \multicolumn{2}{|c|}{$\begin{array}{c}\text { Favourable Outcome/ } \\
\text { Discharged }\end{array}$} & $\begin{array}{c}10 \\
(29 \%)\end{array}$ & $\begin{array}{c}10 \\
(63 \%)\end{array}$ & $\begin{array}{c}20 \\
(39 \%)\end{array}$ & $\begin{array}{c}P= \\
0.02\end{array}$ \\
\hline \multicolumn{2}{|c|}{$\begin{array}{c}\text { Unfavourable Outcome/ } \\
\text { Mortality }\end{array}$} & $\begin{array}{c}25 \\
(71 \%)\end{array}$ & $\begin{array}{c}6 \\
(37 \%)\end{array}$ & $\begin{array}{c}31 \\
(61 \%)\end{array}$ & $\begin{array}{l}P= \\
0.02\end{array}$ \\
\hline
\end{tabular}

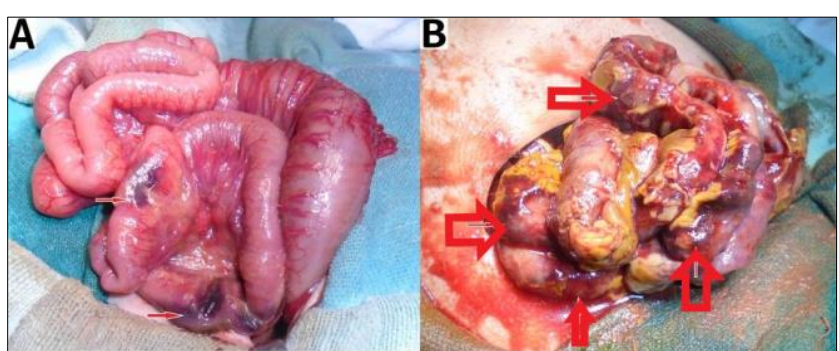

Figure 2: Intraoperative images showing: (A) multiple gangrenous patches in the small intestine (red arrow) and (B) diffuse involvement (ischemia) of small bowel with flakes and pus over gangrenous areas (red arrow).

\section{DISCUSSION}

Necrotizing enterocolitis is one of the main causes of morbidity and mortality in newborn. $[7,8]$ It remains the most common gastrointestinal emergency in neonates, since its description by Siebold in 1825.[9] The morbidity and mortality are worst among the smallest and most premature neonates with survival ranging from 41 to $55 \%$.[10,11] Highest incidence is observed in the very low birth weight, black, male neonates.[12] Similarly in our study group, most of the patients were male $(77 \%)$, low birth weight $(52 \%)$, and premature (55\%). Other risk factors include asphyxia during the perinatal period, preterm newborn with a history of enteral feeding, congenital cardiac anomalies, packed red blood cell transfusion, and umbilical catheterization. [13,14] History of multiple blood transfusions was present in $9 \%$, while umbilical catheterization was performed in $2 \%$ of cases in our series.

NEC is classified according to the staging criteria proposed by Bell et al. (1978) as stage I (suspected NEC), stage II (proven NEC), and stage III (advanced NEC).[5] This classification was later improved by Walsh and Kliegman in 1986 [Table 1].[5,6] In this modified scheme, stages are further subdivided into A or B depending on the radiographic findings.[5,6]

In patients with suspected NEC, a radiological evaluation can confirm the staging as proven or advanced.[2,15,16] Extraluminal air (free air) is the sole radiologic finding that is considered as direct evidence of perforation and has been accepted widely as an indication for surgery.[17] In suspicious cases, abdominocentesis can be performed to ascertain the peritoneal contents and confirming the presence of free air.[18] As per our study, pneumoperitoneum was the indication for surgery in $69 \%$ of patients, a proportion that was greater than those reported by other studies.[19,20,21] Indications for surgery in one of the studies were clinical deterioration (37\%), presence of abdominal mass(15\%), and positive peritoneal tap $(5 \%)$. In the absence of pneumoperitoneum, we considered surgery in $31 \%(16 / 51)$ patients based on clinical deterioration, metabolic derangement, features of intestinal obstruction i.e. fixed dilated bowel 
loops [Figure 3], transient thickening of the intestinal wall [Figure 4]. In group B, during surgery, 11/16 (69\%) had actual perforation, even in the absence of pneumoperitoneum. Similar criteria were taken up by Villamil et al; in their study, intraoperative perforation was seen in $39 \%$ of the patients with no radiological pneumoperitoneum. [20]

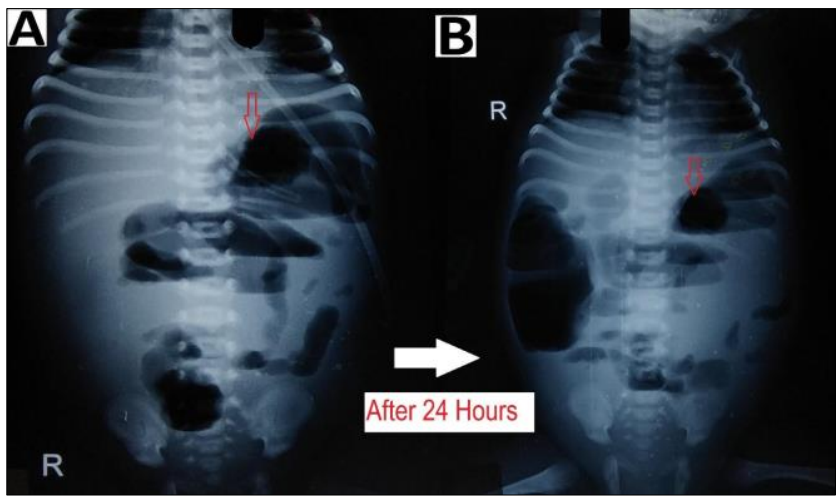

Figure 3: Preoperative radiographs showing: (A) dilated bowel loops (red arrow) at the left upper abdomen and (B) fixed dilated bowel loops (red arrow) at an interval of 24 hours

Surgical intervention was the mainstay of management for NEC in our study, while according to one recent study, an exploratory laparotomy was performed in only $17 \%$ of cases with stage IIIB NEC.[22] The remaining $83 \%$ of patients were managed with peritoneal tapping.[22] Some of these patients (abovementioned study) could have spontaneous pneumoperitoneum i.e. an intraperitoneal gas without gastrointestinal tract perforation, for which no clear etiology was identified.[18] NEC with a small necrotic portion of the bowel may sometimes respond to peritoneal drain placement,[20]. Primary peritoneal drainage is a useful adjunct to resuscitation, but not an alternative to laparotomy, which is recommended when an optimum response is accomplished.[19]

Surgical intervention in NEC must be performed when intestinal gangrene occurs, i.e. during the golden period before the gangrene produces perforation (pneumoperitoneum). Less than 10\% of patients with surgical NEC show findings of other highly specific signs of intestinal necrosis like abdominal wall erythema and fixed abdominal mass.[4] About one-fourth (25\%) of patients of Group $B$ (in our series) had abdominal wall erythema, while fixed abdominal mass was seen in only $6 \%$ of cases. In patients who are in stage I and stage II NEC, the surgical decision can be contemplated (as also performed in our study) in presence of (a) increased abdominal distension, (b) metabolic irregularity and increased acidosis, (c) thrombocytopenia, (d) hypotension leading to increased inotropic support, (e) increased ventilator support.

Some authors consider clinical deterioration (metabolic derangement) as a sufficient primary indication for surgery and have established a series of laboratory criteria and thresholds to determine the appropriateness of intervention, even when pneumoperitoneum is absent.[8] In another study by Tepas et al, the presence of irregularity in the metabolic condition of the patient helped take the surgical decisions.[23] Thirty-seven percentage of patients in Group B (present study) had features of clinical deterioration and the same percentage had thrombocytopenia. Also when medical treatment fails (including antibiotic therapy, discontinuation of enteral feeding, and supportive care), the decision to perform surgery afterward is based on metabolic derangement.[24]

Pneumoperitoneum was appreciated in $50-75 \%$ of patients with intestinal perforation due to NEC, [25] while another study reported it to range from 12$50 \%$.[16] In a study conducted in 2002, the sensitivity and specificity of pneumoperitoneum were estimated at $52 \%$ and $92 \%$, respectively.[26] Intraoperatively, $46(90 \%)$ patients were diagnosed with perforation, while pneumoperitoneum was elicited in 35 (69\%) out of 51 cases (Fig. 1). Thus, the sensitivity of this radiographic finding is much lower than expected. There are several possible explanations for the absence of pneumoperitoneum in cases of intestinal perforation. $[9,20]$

Intestinal distension, often secondary to obstruction, is the most common sign visible in $90 \%$ of radiograms in neonates with NEC.[2] Although no evidence-based guidelines are available regarding the duration and frequency of radiographic examination, an attempt was made by Coursey et al. in 2009 using a ten-point scale for abnormal radiographic findings in infants with clinically suspected NEC.[24] They called it Duke's Abdominal Assessment Scale (DAAS score). Findings of fixed (unchanging) bowel loops, definite pneumatosis, or portal venous gas as revealed by DAAS scores of 7,8 , or 9 were highly associated with eventual surgical intervention for suspected NEC.[25]

Bowel wall thickening from oedema and haemorrhage is seen as separated bowel loops on radiographs. [15] Increased bowel wall thickening on radiographs in presence of clinical features is an early sign of NEC (Fig.4). A wall thickness greater than $2.6 \mathrm{~mm}$ is a pathological finding on ultrasound. [21]

When intraperitoneal fluid is present in the abdomen, the gas-filled loops of the bowel float centrally in the abdomen and are separated from each other by the fluid. [15] In case of ascites (without pneumoperitoneum) due to small bowel perforation in $\mathrm{NEC}$, the peritoneal fluid settles in the lower abdomen with relatively few small bowel loops in the upper abdomen (Fig.4). Ultrasound is more sensitive and specific for diagnosing intraperitoneal fluid; whether it is free in the peritoneal cavity or a more localized fluid collection. The presence of echogenic ascites or 
septations within the fluid is highly suggestive of perforation.[2]

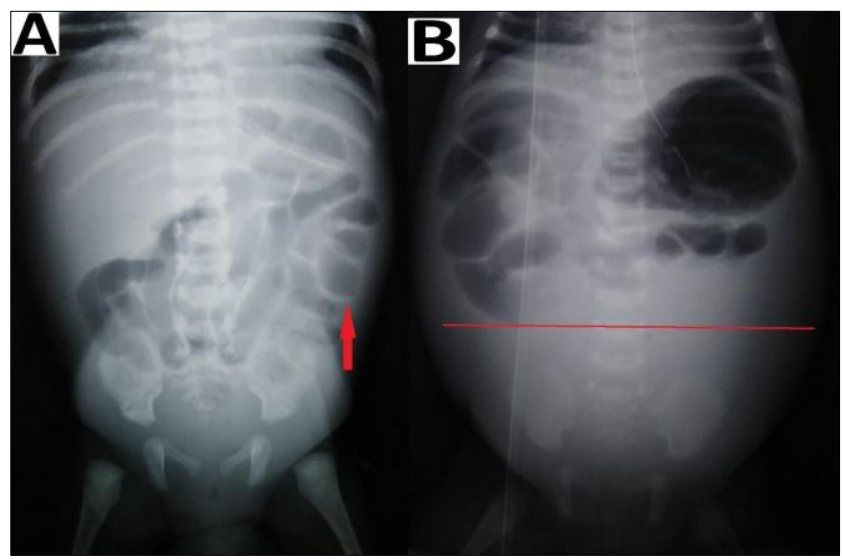

Figure 4: Preoperative radiographs showing: (A) increased bowel wall thickening (red arrow) and (B) dilated small bowel loops in the upper abdomen with ground glass appearance in the lower abdomen (below the red line).

Intestinal pneumatosis is a pathognomonic sign for NEC. According to different sources, detecting this sign in ultrasound varies between $13 \%$ and $100 \%$, while in radiograms, it ranges from 20 to 95\%.[21] A linear (crescent) gas pattern (Fig.5) is a more specific sign than the bubbly (foamy) gas pattern.[15]

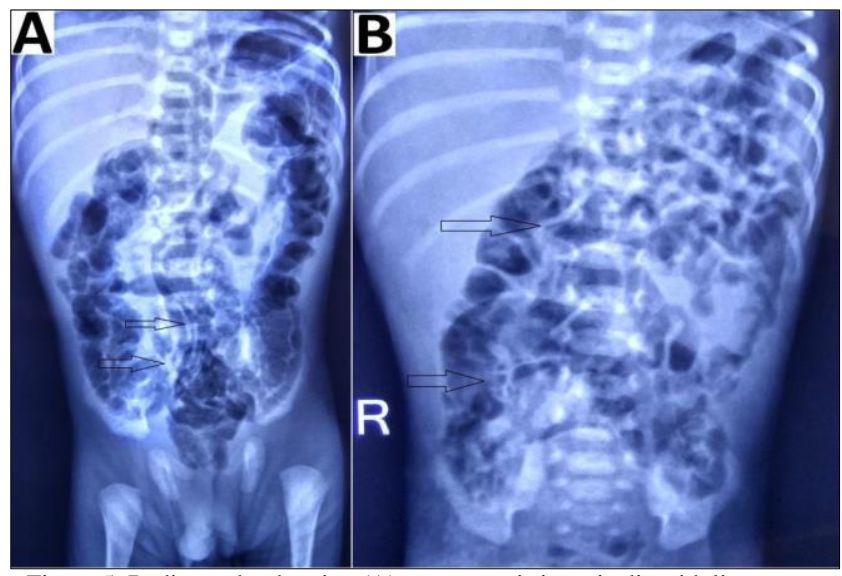

Figure 5: Radiographs showing (A) pneumatosis intestinalis with linear gas pattern (black arrow) and (B) bubbly gas pattern (black arrow).

Portal venous gas secondary to resorption of air bubbles from the intestine into the portal venous system is less common than intestinal pneumatosis. The diagnostic utility of ultrasound in the detection of this sign is higher than that of x-ray examination.[26]

Ultrasound can predict adverse outcomes in NEC, particularly by displaying free intraperitoneal gas and focal fluid collections (focal fluid collections are indicative of intestinal perforation).[27] It can depict bowel wall thickness and echogenicity. Doppler ultrasound can identify necrotic bowel segments in NEC based on blood flow, calibre, and peristalsis.[3] The sensitivity of this examination reaches $100 \%$ when the assessment includes evaluation of perfusion, which shows the absence of blood flow in the abnormal intestinal fragment.[27]

We detected fixed bowel loops in 3 patients (18\%) pneumatosis intestinalis (Fig.5) in $1(6 \%)$, portal venous gas in 1 (6\%), and massive ascites (Fig.4) in 2 patients $(12 \%)$ among the group B (with the absence of pneumoperitoneum). These percentages (findings) were relatively small in our study, but in presence of clinical signs, they contributed towards deciding to operate in our study. Thus collectively (clinicoradiologically), more than one sign according to Modified Bell's staging was present in group B patients, i.e. $8(50 \%)$ stage IIIA, $12(75 \%)$ stage IIB, 1 (6\%) stage IIA and $3(18 \%)$ stage IA/IB.

There is limited literature on the interval between the presentation of symptoms and the perforation of the bowel. [28] A study revealed that bowel perforation occurred in $24 \%$ of neonates with NEC and occurred at the median interval of 1 day after the presenting symptoms.[7] In our series, 53\% of the patients were referred to the surgical unit after primary treatment in medical NICUs and the average time duration of symptoms was 4.1 days before being diagnosed. This implies the delay in decision making during Stage I and II and waiting for the appearance of definitive signs for surgery i.e. pneumoperitoneum among the patients. This contributed towards the overall mortality of $61 \%$ in our study. The overall mortality was $41.5 \%$ in a similar recent study.[20] A high mortality rate of 20 to $60 \%$ was noted according to various studies, thus early diagnosis is crucial to avoid morbidity and mortality.[2] Individually the mortality rate was higher $(71 \%)$ in Group A than Group B (37\%). In another study, the mortality rate was higher in the group without pneumoperitoneum $(55 \%)$ than in patients with pneumoperitoneum (45\%). [20]

It is imperative that a high index of suspicion for NEC with necrotic bowel should be present because early recognition and treatment may minimize the unfavourable outcomes. An early paediatric surgical consultation is recommended in each patient of suspected NEC, especially for cases with confirmed stage II NEC. [14]

Evenett et al. carried out a systematic review on studies that carried out serological tests that may be useful in the diagnosis of NEC.[29] Attempts to identify biochemical markers specific to NEC have not been successful and remain an area of ongoing research. Preventive measures include (a) improving the nutritional status and care of the mother during the pregnancy to improve the birth weight of newborn, (b) institutional delivery of babies with birth defects, (c) encouraging human milk (breast) feeding, and probiotic supplementation.[14,30] 
Our mortality statistics are reasonably high in comparison to other large series $(61 \%$ mortality in our study versus $41.5 \%$ in others).[2,14,20] This is owing to: (i) Patient characteristics: late presentation to tertiary centres (mean duration of symptoms in our study was 4.1 days (1-10),[20] delayed diagnoses (mean duration of conservative treatment in medical NICUs was 8.6 days (1-15),[20] presence of sepsis, undiagnosed associated malformations/anomalies; (ii) Resources: poor health care infrastructure and transportation structure, lack of equipped neonatal ICU with trained personnel, poor patient-staff ratio, overcrowding leading to cross-infection and septicemia.

Finally, the complication rate was significantly higher $(77 \%)$ in Group A than Group B $(43 \%)$. The mortality rate was also significantly higher $(71 \%)$ in Group A than in Group B (37\%). The statistically significant results show that the survival rate is better in neonates without pneumoperitoneum (group B) i.e. in whom the intervention was performed early. Thus, it is crucial to establish the diagnosis as early as possible.[31] Recommendations for improving the favourable outcomes are bedside, round-the-clock digital radiography facilities for early diagnosis with radiological signs of NEC and availability of highresolution Doppler ultrasonography facilities for early

\section{REFERENCES}

1. Papillon S, Castle SL, Gayer CP, Ford HR. Necrotizing enterocolitis: contemporary management and outcomes. Adv Pediatr. 2013; 60:263-79.

2. Epelman M, Daneman A, Navarro OM, Morag I, Moore $\mathrm{AM}$, Kim JH, et al. Necrotizing enterocolitis: review of state-of-the-art imaging findings with pathologic correlation. Radiographics. 2007; 27:285-305.

3. Raval MV, Moss RL. Current concepts in the surgical approach to necrotizing enterocolitis. Pathophysiol. 2014; 21:105-10.

4. Kosloske AM. Indications for operation in necrotizing enterocolitis revisited. J Pediatr Surg. 1994; 29:663-6.

5. Bell MJ, Ternberg JL, Feigin RD, Keating JP, Marshall $\mathrm{R}$, Barton L, et al. Neonatal necrotizing enterocolitis. Therapeutic decisions based upon clinical staging. Ann Surg. 1978; 187:1-7.

6. Walsh MC, Kliegman RM. Necrotizing enterocolitis: treatment based on staging criteria. Pediatr Clin North Am. 1986; 33:179-201.

7. Najaf TA, Vachharajani NA, Warner BW, Vachharajani AJ. Interval between clinical presentation of necrotizing enterocolitis and bowel perforation in neonates. Pediatr Surg Int. 2010; 26:607-9.

8. Upadhyaya VD, Gangopadhyay AN, Pandey A, Upadhyaya A, Mohan TV, Gopal SC, et al. Is pneumoperitoneum an absolute indication for surgery in necrotizing enterocolitis? World J Pediatr. 2008; 4:41-4.

9. Kosloske AM, Papile LA, Burstein J. Indications for operation in acute necrotizing enterocolitis of the neonate. Surg. 1980; 87:502-8. diagnosis of gangrenous bowel and to prevent the undesired complications associated with delayed diagnosis

\section{CONCLUSION}

Appropriate and correct timing of surgery in the treatment of NEC is a very controversial issue. There is widespread agreement that the prognosis of patients with NEC is worsened once intestinal perforation has occurred. Since disease progression is very rapid, it is crucial to establish the diagnosis as early as possible. The decision to operate must be based on the cumulative assessment of clinical and radiologic findings of the patient, especially in the absence of pneumoperitoneum to improve survival rates. Early diagnosis and prompt surgical intervention when indicated can improve survival in patients with NEC.

\section{Acknowledgements: Nil. \\ Conflict of Interest: None \\ Source of Support: $\mathrm{Nil}$}

Consent to Publication: Author(s) declared taking informed written consent for the publication of clinical photographs/material (if any used), from the legal guardian of the patient with an understanding that every effort will be made to conceal the identity of the patient, however it cannot be guaranteed.

Author Contributions: Author(s) declared to fulfil authorship criteria as devised by ICMJE and approved the final version.

10. Lin PW, Stoll BJ. Necrotising enterocolitis. Lancet. 2006; 368:1271-83.

11. Rowe MI, Reblock KK, Kurkchubasche AG, Healey PJ. Necrotizing enterocolitis in the extremely low birth weight infant. J Pediatr Surg. 1994; 29:987-990.

12. Ng S. Necrotizing enterocolitis in the full-term neonate. J Paediatr Child Health. 2001; 37:1-4.

13. Staryszak J, Stopa J, Kucharska-Miasik I, Osuchowska M, Guz W, Błaz W. Usefulness of ultrasound examinations in the diagnostics of necrotizing enterocolitis. Pol J Radiol. 2015; 80:1-9.

14. Wertheimer F, Arcinue R, Niklas V. Necrotizing enterocolitis: enhancing awareness for the general practitioner. Pediatr Rev. 2019; 40:517-27.

15. Morrison SC, Jacobson JM. The radiology of necrotising enterocolitis. Clin Perinatol. 1994; 21:34763.

16. Dilli D, SunaO־guz S, Erol R, Ozkan-Ulu H, Dumanlı H, Dilmen U. Does abdominal sonography provide additional information over abdominal plain radiography for diagnosis of necrotizing enterocolitis in neonates? Pediatr Surg Int. 2011; 27:321-7.

17. Coursey CA, Hollingsworth CL, Gaca AM, Maxfield C, Delong D, Bisset G 3rd. Radiologists' agreement when using a 10-point scale to report abdominal radiographic findings of necrotizing enterocolitis in neonates and infants. Am J Roentgenol. 2008; 191:190-7.

18. Gupta R. Spontaneous pneumoperitoneum in pediatric patients: Dilemmas in Management. $J$ Indian Assoc Pediatr Surg. 2018; 23:115-22. 
19. Cheu HW, Sukarochana K, Lloyd DA. Peritoneal drainage for necrotizing enterocolitis. J Pediatr Surg. 1988; 23:557-61.

20. Villamil V, Ibieta MF, Ubeda MAG. Correlation between pneumoperitoneum and surgical findings and morbidity and mortality in newborns with necrotising enterocolitis. An Pediatr. (Barc) 2018; 89:205-10.

21. Faingold R, Daneman A, Tomlinson G, Babyn PS, Manson DE, Mohanta A, et al. Necrotizing enterocolitis: assessment of bowel viability with color doppler US. Radiol. 2005; 235:587-94.

22. Pandey A, Singh SP, Gupta V, Verma R. Conservative management of pneumoperitoneum in necrotising enterocolitis- is it possible? J Neonatal Surg. 2016; $5: 12$.

23. Tepas JJ 3rd, Sharma R, Hudak ML, Garrison RD, Pieper P. Coming full circle: an evidence-based definition of the timing and type of surgical management of very low-birth-weight $(<1000 \mathrm{~g})$ infants with signs of acute intestinal perforation. J Pediatr Surg. 2006; 41:418-22.

24. Neu J, Walker WA. Necrotizing enterocolitis. N Engl J Med. 2011; 364:255-64.

25. Coursey CA, Hollingsworth CL, Wriston C, Beam C, Rice $\mathrm{H}$, Bisset G 3rd. Radiographic predictors of disease severity in neonates and infants with necrotizing enterocolitis. AJR Am J Roentgenol. 2009; 193:140813.

26. Tam AL, Camberos A, Applebaum H. Surgical decision making in necrotizing enterocolitis and focal intestinal perforation: predictive value of radiologic findings. $\mathrm{J}$ Pediatr Surg. 2002; 37:1688-91.

27. Silva CT, Daneman A, Navarro OM, Moore AM, Moineddin R, Gerstle JT, et al. Correlation of sonographic findings and outcome in necrotizing enterocolitis. Pediatr Radiol. 2007; 37:274-2.

28. Frey EE, Smith W, Franken Jr EA, Wintermeyer KA. Analysis of bowel perforation in necrotizing enterocolitis. Pediatr Radiol. 1987; 17:380-2.

29. Evennett N, Alexander N, Petrov M, Pierro A, Eaton S. A systematic review of serologic tests in the diagnosis of necrotizing enterocolitis. J Pediatr Surg. 2009; 44:2192201.

30. Agnoni A, Amendola CL. Necrotizing enterocolitis: Current concepts in practice. JAAPA 2017; 30:16-21.

31. Lim JC, Golden JM, Ford HR. Pathogenesis of neonatal necrotizing enterocolitis. Pediatr Surg Int. 2015; 31:509-18. 